\title{
Association between Serum Brain-derived Neurotrophic Factor and 25-OH Vitamin D Levels with Vitamin D Receptors Gene Polymorphism (rs2228570) in Patients with Autoimmune Thyroiditis and Hypothyroidism
}

\author{
Iryna Kamyshna ${ }^{1 *}$, Larysa Pavlovych ${ }^{2}$, Aleksandr Kamyshnyi $^{3}$ \\ ${ }^{1}$ Department of Medical Rehabilitation, I. Horbachevsky Ternopil National Medical University, Ternopil, Ukraine; ${ }^{2}$ Department \\ of Clinical Immunology, Allergology and Endocrinology, HSEEU, Bukovinian State Medical University, Chernivtsi, Ukraine; \\ ${ }^{3}$ Department of Microbiology, Virology, and Immunology, I. Horbachevsky Ternopil National Medical University, Ternopil, Ukraine
}

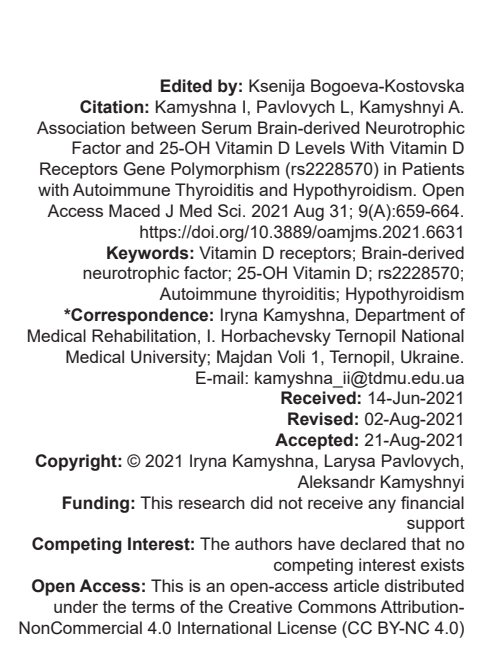

\section{Introduction}

Hashimoto's thyroiditis (HT) is the most recurrent autoimmune thyroid disorder (AITDs). It causes chronic inflammation of the thyroid tissue, with a condition of hypothyroidism in about $20-30 \%$ of patients [1]. Vitamin D plays a role in AIT, as investigated in the past years [2]. Different polymorphisms in Vitamin $D$ receptors (VDR) have an important role in AIT risk [2]. In recent times, several studies have also investigated the association of the four VDR SNPs and HT susceptibility [3]. A growing body of research suggests that patients with HT may suffer from cognitive impairment [4]. Brain-derived neurotrophic factor (BDNF) has been identified as an important growth factor that is involved in learning and memory [5]. BDNF is directly regulated by thyroid hormones and has a key role in developing the fetal brain [6]. BDNF is expressed in a variety of cells, including neurons, and can cross the blood-brain barrier [7]. A prior study demonstrated a positive correlation between BDNF levels and the function of the central nervous system and peripheral nervous system [8]. Moreover, BDNF, expressed in the brain, is involved in the development of mental disorders, and studies show that peripheral BDNF can potentially be used as a marker of these diseases in humans [9]. Previously, we demonstrated that autoimmune thyroiditis (AIT) and hypothyroidism could affect the transcription of the genes involved in neurogenesis, nerve impulse transmission, and cell cycle regulation [10], [11], 12], [13], [14]. These changes in gene expression can play a role in the development 
of neurological complications associated with thyroid pathology.

The aim was to study the linkage of VDR gene polymorphism (rs2228570) with blood serum levels of BDNF and 25-OH Vitamin D in thyroid pathology of patients in the West Ukrainian population.

\section{Materials and Methods}

This research was performed in HSEEU "Bukovinian State Medical University," Chernivtsi Regional Endocrinology Center, and I. Horbachevsky Ternopil National Medical University, Ukraine, from September 2017 to December 2020. The study involved a total of 153 patients with various forms of thyroid pathology. The subjects were divided into three groups. Group $1(n=16)$ included patients with postoperative hypothyroidism (PO); Group $2(n=65)$ included patients with hypothyroidism induced by AIT, and Group 3 $(n=72)$ included patients with both AIT and elevated serum antibodies anti-thyroglobulin (anti-Tg) and antithyroid peroxidase (anti-TPO). Twenty-five healthy individuals were recruited as a control group, randomly and without matching for age or sex.

\section{Ethical approval}

The study fully adhered to principles outlined in the 1975 Helsinki Declaration of Human Rights (amended in 2008). The participants enrolled voluntarily after completing and signing a written informed consent. The approval for this study was obtained from the Ethics Committee of the HSEEU "Bukovinian State Medical University," I. Horbachevsky Ternopil National Medical University and Chernivtsi Regional Endocrinology Center, Ukraine (approval ID: 11-07.11.2017).

Hypothyroidism was diagnosed as recommended by the American Association of Clinical Endocrinologists 2012. When diagnosing AIT, the corresponding clinical features were taken into account, the results of a sonogram of the thyroid gland (reduced echogenicity) and circulating antibodies to thyroid antigens, anti-TPO, and anti-TG were detected [15].

Blood samples from the patients and control individuals were collected in the morning (8-10 AM) after overnight fasting. For each individual who took part in the study, levels of thyroxine (fT4, normal range $6.0-13.0 \mathrm{pmol} / \mathrm{L}$ for males and $7.0-13.5 \mathrm{pmol} / \mathrm{L}$ for females), thyroid-stimulating hormone (normal range $0.3-4.0 \mathrm{mIU} / \mathrm{mL}$ ), anti-TPO (normal range 0-30 IU/mL), and anti-thyroglobulin (anti-TG, normal range $0-65 \mathrm{IU} / \mathrm{mL}$ ) were determined using STAT FAX303/Plus analyzer (Awareness Technology Inc.,
USA).

Study exclusion criteria were as follows: Less than 18 years of age, malignancy, inflammation due to rheumatic diseases or acute/chronic infection, diabetes mellitus, vascular, chronic hepatic or renal diseases, and pregnancy. Individuals taking any drugs that could interfere with thyroid function were also excluded from the study.

BDNF levels in the sera of the patients and healthy individuals were quantified using enzymelinked immunosorbent assay with highly sensitive human BDNF enzyme-linked immunosorbent assay (ELISA) Kit (Elabscience ${ }^{\circledR}$, United States, Catalog No: E-EL-H0010) on E.I.A. Reader Sirio S (Seac, Italy).

25-OH Vitamin D levels in the serum of the patients and healthy individuals were quantified with ELISA using the 25-OH Vitamin D Total (Vitamin D-Direct) Test System ELISA Kit (Monobind Inc. ${ }^{\circledR}$, United States, Product Code: 9425-300) on E.I.A. Reader Sirio S (Seac, Italy).

\section{Genotyping of the VDR (rs2228570) gene polymorphism}

\section{DNA isolation}

To collect venous blood, we used a sterile Vacutainer and stabilized it with K2EDTA. Total DNA was isolated from peripheral blood using PREP-RAPIDGENETICS DNA Extraction Kit (DNA-TECHNOLOGY, Russian Federation), according to the manufacturer's instructions.

\section{DNA amplification and genotyping}

The samples were genotyped using TaqMan probes and TaqMan Genotyping Master Mix (4371355) on CFX96 ${ }^{\mathrm{TM}}$ Real-Time Polymerase Chain Reaction (PCR) Detection System (Bio-Rad Laboratories, Inc., USA). PCR for TaqMan genotyping was carried out according to the kit instructions (Applied Biosystems, USA). TaqMan Genotyping Master Mix contains DNA polymerase AmpliTaq Gold ${ }^{\circledR}$, dNTPs, reference dye ROX $^{\mathrm{TM}}$, and buffer ingredients. TaqMan probes are target-specific oligonucleotides with reporter dyes attached to the 5' end of each probe: $\left(\mathrm{VIC}^{\circledR}\right.$ dye on the 5 end of the Allele 1 probe and 6FAM ${ }^{\text {TM }}$ dye on the 5 ' end of the Allele 2 probe), and a non-fluorescent quencher (NFQ) the 3' end of the probe. Genomic DNA was amplified in a $10 \mu \mathrm{L}$ reaction mix containing genomic DNA, forward and reverse primers, fluorescent probes, and TaqMan Genotyping Master Mix. Genotyping of the samples performed on the CFX-Manager TM software using the method of allele discrimination based on the magnitude of relative fluorescence units. 


\section{Statistical analysis}

To determine the difference between groups, we used the Student's t-test, ANOVA, Pearson's $\chi^{2}$ test, odds ratio test, relative odds ratio test, and equality 0 correlation test. The odds ratio and $95 \%$ confidence interval were calculated using binary logistic regression; $p<0.05$ was considered a statistically significant difference between the two groups (Statsoft statistica v.12.0)

\section{Results}

In our present study, we investigated the correlation of a VDR polymorphism at the rs2228570 locus and BDNF serum levels of the patients with various thyroid gland pathologies in the Bukovinian region of Ukraine.

The demographic, clinical, and biochemical characteristics of the participants are presented in Table 1.

Table 1: Demographic, clinical, and biochemical characteristics of study participants

\begin{tabular}{|c|c|c|c|c|}
\hline Variable & $\begin{array}{l}\text { Control group } \\
(\mathrm{n}=25)\end{array}$ & $\begin{array}{l}\text { Patients with } \\
\text { post-operative } \\
\text { hypothyroidism } \\
(\mathrm{PO}, \mathrm{n}=16)\end{array}$ & $\begin{array}{l}\text { Patients with } \\
\text { AIT-induced } \\
\text { hypothyroidism } \\
\text { (AIT with } \\
\text { hypothyroidism, } \\
\mathrm{n}=65 \text { ) }\end{array}$ & $\begin{array}{l}\text { Patients with AIT } \\
\text { and elevated } \\
\text { anti-Tg and anti- } \\
\text { TPO antibodies } \\
\text { (AIT, } n=72 \text { ) }\end{array}$ \\
\hline Age (years) & $46.08 \pm 14.58$ & $47.30 \pm 12.27$ & $46.72 \pm 15.49$ & $45.02 \pm 13.65$ \\
\hline fT4 (pmol/L) & $8.91 \pm 0.97$ & $3.44 \pm 0.31$ & $4.13 \pm 0.52$ & $8.51 \pm 0.82$ \\
\hline TSH (mlU/mL) & $2.67 \pm 0.52$ & $8.61 \pm 0.84$ & $7.09 \pm 0.50$ & $2.38 \pm 0.62$ \\
\hline anti-TPO (IU/mL) & $34.04 \pm 3.70$ & $36.13 \pm 2.78$ & $380.62 \pm 73.42$ & $330.36 \pm 50.23$ \\
\hline anti-TG (IU/mL) & $15.32 \pm 1.97$ & $15.50 \pm 1.90$ & $32.97 \pm 4.27$ & $36.38 \pm 7.70$ \\
\hline $\begin{array}{l}\text { Current dose of } \\
\text { L-thyroxine }(\mu \mathrm{g} / \text { day })\end{array}$ & None & $110.95 \pm 5.25$ & $88.46 \pm 1.55$ & None \\
\hline $\begin{array}{l}\text { 25-OH Vitamin D } \\
\mathrm{ng} / \mathrm{mL}\end{array}$ & $39.2 \pm 6.58$ & $\begin{array}{l}20.69 \pm 3.09 \\
(p<0.001)\end{array}$ & $\begin{array}{l}19.08 \pm 3.144 \\
(p<0.001)\end{array}$ & $\begin{array}{l}21.48 \pm 2.83 \\
(p<0.001)\end{array}$ \\
\hline BDNF (pg/ml) & $\begin{array}{l}1037.8 \pm \\
361.83\end{array}$ & $\begin{array}{l}310.19 \pm \\
112.84 \\
(p<0.001)\end{array}$ & $\begin{array}{l}329.34 \pm \\
312.57 \\
(p<0.001)\end{array}$ & $\begin{array}{l}1031.34 \pm 385 \\
(p=0.95)\end{array}$ \\
\hline
\end{tabular}

TSH: Thyroid-stimulating hormone.

We analyzed BDNF levels in patients with different thyroid pathology depending on the VDR rs2228570 genotype (Table 2).

Our study detected a significant decrease in the level of BDNF in the study group in carriers of AA and $A G$ genotypes in 1.58 and 2.39 times, respectively, compared with carriers of AA genotype of the control group (Table 2).

At the same time, a significant difference in the level of BDNF between different genotypes of VDR rs2228570 in the experimental group was not observed.

When conducting a comparative analysis of BDNF contentin carriers of different genotypes, depending on thyroid pathology, the lowest indices were in the group of patients with $\mathrm{PO}$. Thus, in patients with AA genotype in the group of patients with PO, the level of BDNF was significantly lower by 3.44 compared with carriers of AA genotype in the control group and patients with $A G$ and
Table 2: BDNF levels in patients with different thyroid pathology depending on the VDR rs2228570 genotype

\begin{tabular}{|c|c|c|c|c|c|c|}
\hline \multicolumn{7}{|c|}{$\mathrm{rs} 2228570(\mathrm{M} \pm \mathrm{m})$} \\
\hline VDR genotype & AA & AG & GG & P5 & P6 & P7 \\
\hline $\begin{array}{l}\text { Control group, } \\
\mathrm{n}=25\end{array}$ & $\begin{array}{l}1006.82 \pm \\
341.62(9)\end{array}$ & $\begin{array}{l}1134.5 \pm 357.83 \\
(9)\end{array}$ & $\begin{array}{l}945.8 \pm \\
439.77(7)\end{array}$ & 0.51 & 0.8 & 0.45 \\
\hline $\begin{array}{l}\text { Study group, } \\
n=153 \\
P 1\end{array}$ & $\begin{array}{l}637.51 \pm \\
490.75(59) \\
0.038\end{array}$ & $\begin{array}{l}474.98 \pm \\
q 351.38(64) \\
0.00164\end{array}$ & $\begin{array}{l}480.69 \pm \\
363.58(30) \\
0.081\end{array}$ & 0.193 & 0.3034 & 0.96 \\
\hline $\mathrm{PO}, \mathrm{n}=16$ & $\begin{array}{l}292.67 \pm \\
127.42(7)\end{array}$ & $\begin{array}{l}289.02 \pm 75.12 \\
(6)\end{array}$ & $\begin{array}{l}373.47 \pm \\
139.71(3)\end{array}$ & 0.95 & 0.45 & 0.45 \\
\hline P1 & $<0.001$ & $<0.001$ & 0.041 & & & \\
\hline P2 & 0.0559 & 0.171 & 0.958 & & & \\
\hline $\begin{array}{l}\text { AIT with } \\
\text { hypothyroidism } \\
n=65\end{array}$ & $\begin{array}{l}351.74 \pm \\
265.58(20)\end{array}$ & $\begin{array}{l}434.75 \pm \\
339.24(33)\end{array}$ & $\begin{array}{l}363.27 \pm \\
380.11(12)\end{array}$ & 0.51 & 0.95 & 0.72 \\
\hline $\mathrm{P} 1$ & 0.0014 & 0.0012 & 0.056 & & & \\
\hline P3 & $<0.001$ & 0.136 & 0.09 & & & \\
\hline AIT $n=72$ & $\begin{array}{l}1085.4 \pm \\
425.31(32)\end{array}$ & $\begin{array}{l}897.3 \pm 355.98 \\
(25)\end{array}$ & $\begin{array}{l}935.05 \pm \\
237.52(15)\end{array}$ & 0.4836 & 0.539 & 0.896 \\
\hline P1 & 0,672 & 0.391 & 0.96 & & & \\
\hline P4 & $<0.001$ & 0.093 & 0.135 & & & \\
\hline $\begin{array}{l}\text { Statistical significa } \\
\text { P2 - p-value betw } \\
\text { hypothyroidism gr } \\
\text { genotypes. P6 - } \\
\text { VDR V Vitamin D }\end{array}$ & e of difference & $p<0.05 . P 1-p-v_{c}$ & e between the & ntrol gr & and stu & $\begin{array}{l}\text { roups. } \\
\text { with } \\
\text { iG } \\
\text { ypes. }\end{array}$ \\
\hline
\end{tabular}

GG genotypes, the level of BDNF was reduced by 3.92 and 2.53 folds, respectively.

When examining patients with AIT with hypothyroidism, the level of BDNF in carriers of the AA genotype was reduced by 2.86 times compared to the AA genotype carriers in the control group. Among carriers of the AG genotype, the BDNF level was significantly lower by 2.6 times compared with the control. In carriers of the GG genotype of patients with AIT with hypothyroidism, the BDNF content did not significantly differ from the control group.

No significant changes in BDNF levels were observed in patients with AIT compared with the control group in carriers of all three genotypes.

Carriers of AA genotype showed a probable decrease in BDNF levels in patients with AIT with hypothyroidism by 3.1 times compared with carriers of AA genotype in the group of patients with AIT.

In addition, the carriers of AA genotype in the group of patients with PO, the level of BDNF was also significantly reduced by 3.7 times compared with carriers of AA genotype among patients with AIT.

However, in a detailed analysis of the BDNF content between carriers $A A, A G$, and $G G$ in patients of all three groups, depending on the pathology of the thyroid gland, we did not find a significant difference.

Table 3 provides evidence that the rs 2228570 VDR polymorphism is not a risk factor for reduced serum BDNF levels.

Table 3: Polymorphic variants of the VDR gene rs2228570 as risk factors for reduced serum

\begin{tabular}{|c|c|c|c|c|c|}
\hline \multicolumn{6}{|l|}{ BDNF levels } \\
\hline VDR gene rs2228570 & RelR & OR & $95 \% \mathrm{Cl}$ RR & $95 \% \mathrm{Cl}$ OR & $\mathrm{p}$ \\
\hline \multicolumn{6}{|l|}{ BDNF level <500 } \\
\hline AA & 1.053 & 1.14 & $0.6799 ; 1.63$ & $0.3157 ; 4.3254$ & 1 \\
\hline$A G$ & 1.053 & 1.14 & $0.6799 ; 1.63$ & $0.3157 ; 4.3254$ & 1 \\
\hline GG & 0.9211 & 0.7048 & $0.6717 ; 1.2629$ & $0.1577 ; 3.336$ & 0.734 \\
\hline
\end{tabular}




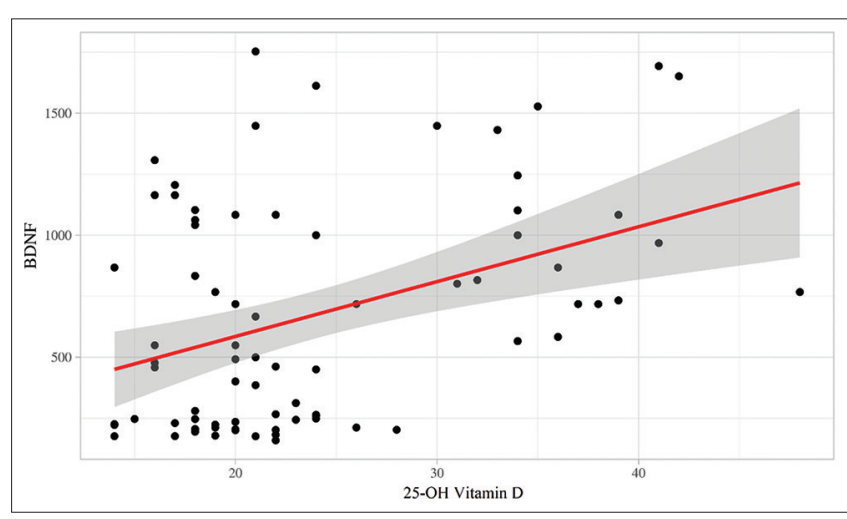

Figure 1: Correlation analysis of the dependence of the "BDNF" indicator on the "Vit D" indicator

An analysis of the correlation between BDNF levels and the levels of 25-OH Vitamin D shows a moderate direct relationship $(r=0.4)$ between BDNF and 25-OH Vitamin D ( $p=0.006)$.

The graph of the regression function, characterizing the dependence of the "BDNF" indicator on the "Vit D" indicator is given in Figure 1. The observed dependence of the "BDNF" indicator on the "Vit D" indicator is described by the equation of paired linear regression:

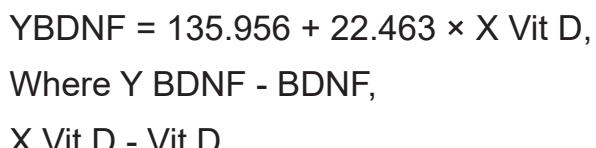

With an increase in Vitamin $D$ by 1 , an increase in BDNF by 22.463 should be expected. By the coefficient of determination $\mathrm{R} 2$ in the resulting model, $15.73 \%$ of the factors influencing the value of the "BDNF" indicator were taken into account.

\section{Discussion}

BDNF significantly impacts memory formation and brain development, namely, neurogenesis, synaptogenesis, and neuronal differentiation [16]. Previous investigations have detected that thyroid hormones play an essential role in BDNF expression [17]. An essential method used for identifying a hereditary predisposition to certain diseases is based on the analysis of transcriptome [18], [19] and single-nucleotide polymorphism [20], [21], [22].

According to the current evidence, four polymorphisms of the VDR gene (Taql (rs731236, alleles T/t), Apal (rs7975232, alleles A/a), Fokl (rs2228570, alleles F/f), and Bsml (rs1544410, alleles $B / b$ ) are associated with the HT risk. However, studies focusing on these polymorphisms have shown discrepant results. A meta-analysis of 11 case-control studies has been conducted intending to establish an association between the four polymorphisms and HT susceptibility [2].

When conducting a comparative analysis of the BDNF content in carriers of different genotypes of VDR rs2228570, considering the pathology of the thyroid gland, the lowest indices in the group of patients with PO were detected. Consequently, in patients with the AA genotype in the group of patients with $P O$, the BDNF level was significantly lower by 3.44 compared to carriers of the AA genotype in the control group and patients with the AG and GG genotypes, the BDNF level was reduced by 3.92 and 2, 53 folds correspondingly.

During the examination of patients with AIT with hypothyroidism, the BDNF level in carriers of the AA genotype decreased 2.86 times when compared to carriers of the AA genotype in the control group. Among carriers of the AG genotype, the level of BDNF was significantly lower by 2.6 times compared to the control. In carriers of the GG genotype in AIT patients with hypothyroidism, the BDNF content did not vary notably from the control group.

Our study outcomes show that the rs2228570 VDR polymorphism is not a risk factor for reduced serum BDNF in patients suffering from different forms of thyroid pathology.

According to the late research, an association between low Vitamin D status and autoimmune thyroid diseases such as HT has been demonstrated. Several clinical studies have reported a low Vitamin $D$ status in AITD or HT, showing an association between Vitamin D deficiency and thyroid autoimmunity [23]. Various studies have demonstrated that Vitamin $D$ is crucial for the normal development of the brain and its function, so Vitamin $D$ deficiency has been linked with neurological disorders [24].

The study also detected a decrease in hippocampal BDNF levels in a preclinical model of depression, which made normal with Vitamin D supplementation (Goltz et al., 2017). Vitamin D influences the development and functioning of the brain and the regulation of neurotrophic factors. In our study, analysis of the correlation between serum BDNF levels and $25-\mathrm{OH}$ Vitamin $\mathrm{D}$ levels shows a moderate direct relationship $(r=0.4)$ between BDNF and 25-OH Vitamin $D(p=0.006)$.

\section{Conclusions}

Our study revealed a significant decrease in the BDNF level in the study group in carriers of the $A A$ and $A G$ genotypes by 1.58 and 2.39 times, corresponding, compared with carriers of the AA genotype in the control group. Concurrently, there was no significant difference in the BDNF level between different genotypes of VDR rs2228570 in the research 
group. In addition, the rs2228570 VDR polymorphism is not a risk factor for decreased serum BDNF levels. At the same time, our study found a moderate direct relationship between serum BDNF levels and $25-\mathrm{OH}$ Vitamin D ( $p=0.006)$.

It is necessary to conduct ongoing and future long-term randomized controlled trials that will provide insight into the efficacy and safety of Vitamin D as a therapeutic efficacy for these thyroid diseases as the prevention and treatment of neurological complications.

\section{Acknowledgments}

\section{Ethical approval}

The approval for this study was obtained from the Ethics Committee of the HSEEU "Bukovinian State Medical University" and Chernivtsi Regional Endocrinology Center, Ukraine (approval ID: 11-07.11.2017).

Our study was conducted according to the Declaration of Helsinki adopted in 1975 and revised in 2008, and the ethical principles were entirely respected.

\section{References}

1. Tillmann FP, Harth A, Jörres A. Hashimoto's thyroiditis-associated acute renal failure and pitfalls of eGFR interpretation in thyroid diseases. Eur J Case Rep Intern Med. 2021;8(7):002645. https://doi.org/10.12890/2021_002645

PMid:34268270

2. Krysiak R, Kowalcze K, Okopień B. The impact of exogenous Vitamin $\mathrm{D}$ on thyroid autoimmunity in euthyroid men with autoimmune thyroiditis and early-onset androgenic alopecia. Pharmacol Rep. 2021. https://doi.org/10.1007/ s43440-021-00295-3

PMid:34106452

3. Zhou F, Liang Z, Wang X, Tan G, Wei W, Zheng G, et al. The VDR gene confers a genetic predisposition to Graves' disease and Graves' ophthalmopathy in the Southwest Chinese Han population. Gene. 2021;793:145750. https://doi.org/10.1016/j. gene.2021.145750

PMid:34077777

4. Valencia-Sanchez C, Pittock SJ, Mead-Harvey C, Dubey D, Flanagan EP, Lopez-Chiriboga S, et al. Brain dysfunction and thyroid antibodies: Autoimmune diagnosis and misdiagnosis. Brain Commun. 2021;3(2):fcaa233. https://doi.org/10.1093/ braincomms/fcaa233

PMid:34061124

5. Sable HJ, MacDonnchadh JJ, Lee HW, Butawan M, Simpson RN, Krueger KM, Bloomer RJ. Working memory and hippocampal expression of BDNF, ARC, and P-STAT3 in rats: Effects of diet and exercise. Nutr Neurosci. 2021.1-14. https://doi.org/10.1080 /1028415x.2021.1885230

PMid:33593241
6. Hung PL, Hsu MH, Yu HR, Wu KL, Wang FS. Thyroxin protects white matter from hypoxic-ischemic insult in the immature Sprague-Dawley rat brain by regulating periventricular white matter and cortex BDNF and CREB pathways. Int J Mol Sci. 2018;19(9):2573. https://doi.org/10.3390/ijms19092573

\section{PMid:30158497}

7. Puhlmann LM, Linz R, Valk SL, Vrticka $P$, de Wael RV, Bernasconi A, et al. Association between hippocampal structure and serum brain-derived neurotrophic factor (BDNF) in healthy adults: A registered report. Neuroimage. 2021;236:118011. https://doi.org/10.1016/j.neuroimage.2021.118011

PMid:33852941

8. Xiong LL, Chen J, Du RL, Liu J, Chen YJ, Hawwas MA, et al. Brain-derived neurotrophic factor and its related enzymes and receptors play important roles after hypoxic-ischemic brain damage. Neural Regen Res. 2021;16(8):1453-9. https://doi. org/10.4103/1673-5374.303033

PMid:33433458

9. Peters RB, Xavier J, Mondin TC, Cardoso TA, Ferreira FB, Teixeira L, et al. BDNF Val66Met polymorphism and resilience in major depressive disorder: The impact of cognitive psychotherapy. Braz J Psychiatry. 2021;43:22-8. https://doi. org/10.1590/1516-4446-2019-0726

PMid:32844885

10. Bilous I, Pavlovych L, Krynytska I, Marushchak M, Kamyshnyi A. Apoptosis and cell cycle pathway-focused genes expression analysis in patients with different forms of thyroid pathology. Open Access Maced J Med Sci. 2020;8(B):784-92. https://doi. org/10.3889/oamjms.2020.4760

11. Bilous II, Korda MM, Krynytska IY, Kamyshnyi AM. Nerve impulse transmission pathway-focused genes expression analysis in patients with primary hypothyroidism and autoimmune thyroiditis. Endocr Regul. 2020;54(2):109-18. https://doi.org/10.2478/enr-2020-0013 PMid:32597152

12. Bilous II, Pavlovych LL, Kamyshnyi AM. Primary hypothyroidism and autoimmune thyroiditis alter the transcriptional activity of genes regulating neurogenesis in the blood of patients. Endocr Regul. 2021;55(1):5-15. https://doi.org/10.2478/enr-2021-0002 PMid:33600668

13. Kamyshna II, Pavlovych LB, Maslyanko VA, Kamyshnyi AM Analysis of the transcriptional activity of genes of neuropeptides and their receptors in the blood of patients with thyroid pathology. J Med Life. 2021;14(2):243-9.

PMid:34104248

14. Kamyshna I, Kamyshnyi A. Transcriptional activity of neurotrophins genes and their receptors in the peripheral blood in patients with thyroid diseases in Bukovinian population of Ukraine. Open Access Maced J Med Sci. 2021;9(A):208-16. https://doi.org/10.3889/oamjms.2021.6037

15. Garber JR, Cobin RH, Gharib H, Hennessey JV, Klein I, Mechanick JI, et al. Clinical practice guidelines for hypothyroidism in adults: Cosponsored by the American association of clinical endocrinologists and the American thyroid association. Endocr Pract. 2012;18(6):988-1028. https://doi.org/10.4158/ep12280.gl PMid:23246686

16. Sonoyama T, Stadler LKJ, Zhu M, Keogh JM, Henning E, Hisama F, et al. Human BDNF/TrkB variants impair hippocampal synaptogenesis and associate with neurobehavioural abnormalities. Sci Rep. 2020;10(1):9028. https://doi. org/10.1038/s41598-020-65531-x PMid:32493978

17. Shabani S, Farbood Y, Mard SA, Sarkaki A, Ahangarpour A, Khorsandi $\mathrm{L}$. The regulation of pituitary-thyroid abnormalities by peripheral administration of levothyroxine increased brainderived neurotrophic factor and reelin protein expression in an 
animal model of Alzheimer's disease. Can J Physiol Pharmacol. 2018;96(3):275-80. https://doi.org/10.1139/cjpp-2016-0434 PMid:28846851

18. Degen AS, Krynytska IY, Kamyshnyi AM. Changes in the transcriptional activity of the entero-insular axis genes in streptozotocin-induced diabetes and after the administration of TNF- $\alpha$ non-selective blockers. Endocr Regul. 2020;54(3):160-71. https://doi.org/10.2478/enr-2020-0019

PMid:32857721

19. Putilin DA, Evchenko SY, Fedoniuk LY, Tokarskyy OS, Kamyshny OM, Migenko LM, et al. The influence of metformin to the transcriptional activity of the mTOR and FOX3 genes in parapancreatic adipose tissue of streptozotocin-induced diabetic rats. J Med Life. 2020;13(1):50-5. https://doi.org/10.1530/ endoabs.49.ep455 PMid:32341701

20. Lyubomirskaya ES, Kamyshnyi AM, Krut YY, Smiianov VA, FedoniukLY, Romanyuk LB, etal.SNPs and transcriptional activity of genes of innate and adaptive immunity at the maternal-fetal interface in woman with preterm labour, associated with preterm premature rupture of membranes. Wiad Lek. 2020;73(1):25-30. https://doi.org/10.14739/2310-1237.2018.2.141400
PMid:32124801

21. Lyubomirskaya K, Krut Y, Sergeyeva L, Khmil S, Lototska O, Petrenko N, et al. Preterm premature rupture of membranes: Prediction of risks in women of Zaporizhzhia region of Ukraine. Pol Merkur Lekarski. 2020;48(288):399-405.

PMid:33387426

22. Dzhuryak V, Sydorchuk L, Sydorchuk A, Kamyshnyi O, Kshanovska A, Levytska S, et al. The cytochrome 11B2 aldosterone synthase gene CYP11B2 (RS1799998) polymorphism associates with chronic kidney disease in hypertensive patients. Biointerface Res Appl Chem. 2020;10(3):5406-11. https://doi.org/10.33263/briac103.406411

23. Kim D. The role of Vitamin $D$ in thyroid diseases. Int $J$ Mol Sci. 2017;18(9):1949.

PMid:28895880

24. Goltz A, Janowitz D, Hannemann A, Nauck M, Hoffmann J, Seyfart T, et al. Association of brain-derived neurotrophic factor and Vitamin D with depression and obesity: A population-based study. Neuropsychobiology. 2017;76(4):171-81. https://doi. org/10.1159/000489864

PMid:29920493 